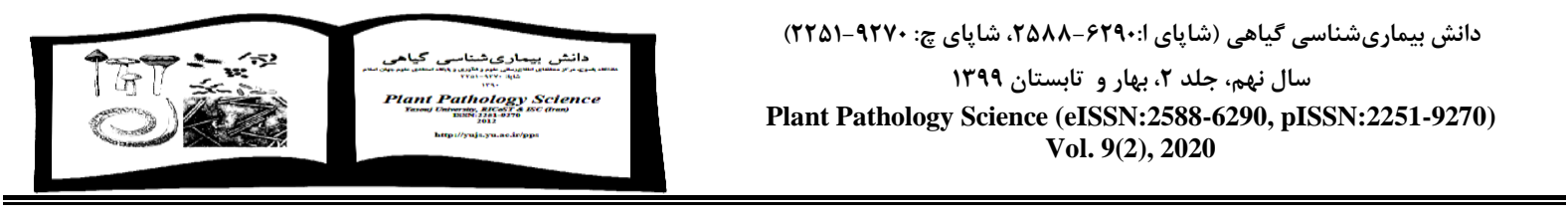

\title{
Research Article \\ Biological control of Fusarium root rot of bean with two Trichoderma species and Pseudomonas fluorescens
}

\author{
ALI ROSTAMI, MEHDI SADRAVI ${ }^{\bowtie}$, RASOOL REZAEI, \\ MOHAMMAD ABDOLLAHI
}

Department of Plant Protection, Faculty of Agriculture, Yasouj University, Yasouj, Iran

$$
\text { Received: 07.02.2020 Accepted: 09.15.2020 }
$$

Rostami A, Sadravi M, Rezaei R, Abdollahi M (2020) Biological control of Fusarium root rot of bean with two Trichoderma species and Pseudomonas fluorescens. Plant Pathology Science 9(2): 14-27. Doi: 10.2982/PPS.9.2.14

\begin{abstract}
Introduction: Fusarium root rot with damage reported up to $85 \%$ of the crop yield, caused by Fusarium solani f. sp. phaseoli, is one of the most important bean diseases in the world. Biological control is a healthy and environmentally friendly way to manage this soil-borne disease. Materials and Methods: Bean farms in Kohgiluyeh and Boyer-Ahmad Province were visited and the rotten roots of diseased plants were sampled. Two isolates of the pathogen were isolated, purified and identified. The pathogenicity of these two isolates was tested on two bean varieties Drakhshan and Pak under greenhouse conditions. The colony growth inhibition rate of the hypervirulant isolate of the pathogen was assessed by 14 native isolates of Trichoderma harzianum, four isolates of Trichoderma virens, two isolates of Trichoderma atroviridae, and five native isolates of Pseudomonas florescens and $P$. florescens $\mathrm{CHAO}$ with hyperparasitic ability and production of antibiotics in vitro. Finally, the effect of four superior T. harzianum isolates, one T. atroviridae isolate and two $P$. florescens isolates on disease severity were examined in a completely randomized design in the greenhouse. Results: All isolates of three species of Trichoderma had the ability to hyperparasite and destroy pathogenic hyphae. Four T. harzianum isolates showed a more significant ability to produce non-volatile and volatile antibiotic materials. All treatments significantly reduced the disease severity, but a $T$. harzianum isolate was more effective in vivo. Conclusion: Fusarium root rot is also found in bean fields in southwestern Iran. Native isolates of $T$. harzianum, $T$. virens and $T$. atroviridae have the hyperparasitic ability on the pathogen. These fungi and isolates of $P$. florescens have the ability to inhibit the growth of the pathogen colony by producing antibiotic substances. Isolates of Trichoderma harzianum, $T$. atroviridae and $P$. florescens $\mathrm{CHAO}$ have the ability to reduce the severity of the disease in vivo.
\end{abstract}

Keywords: Bean, Disease, Fusarium, Hyperparasite, Antibiosis

Corresponding author: msadravi@yu.ac.ir, iD 0000-0002-4324-131X 
مقاله يزوهشى

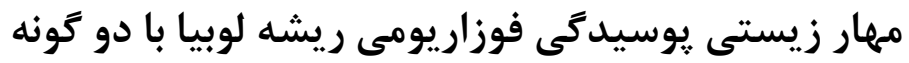

Pseudomonas fluorescens, Trichoderma

$$
\begin{aligned}
& \text { على رستمى، مهدى صدروى هـ , رسول رضائى، محمد عبداللهى } \\
& \text { گروه گياهيزشكى، دانشكده كشاورزى، دانشگاه ياسوج، ياسوج } \\
& \text { دريافت: }
\end{aligned}
$$

رستمى ع، صدروى م، رضائى ر، عبداللهى م (9 9 (1) مهار زيستى يوسيدگى فوزاريومى ريشه لوبيا با دو گونه

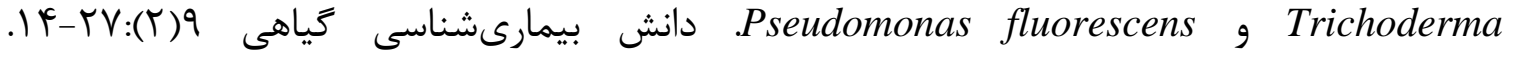

Doi: 10.2982/PPS.9.2.14

\section{جكيده}

مقدمه: يوسيدگى فوزاريومى ريشه، ناشسى از Fusarium solani f. sp. phaseoli ، يكىى از بيمـارىهـاى

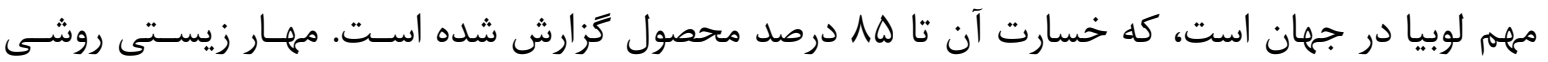
سالم و سازكار با محيط زيست براى مديريت اين بيمارى خاكبرد است. مواد و روشها: مزرعههاى لوبيا در استان كهخيلويه و بويراحمد بازديد شدند و از ريشههاى يوسيده بوتههاى بيمار نمونهبـردارى شـد. دو

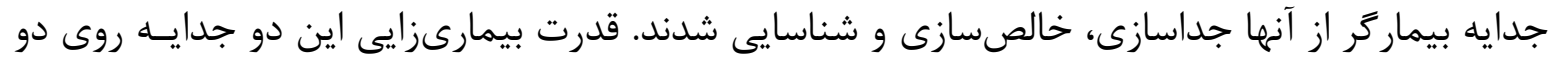
رقم درخشان و ياك لوبيا در گلخانه آزمايش شد. قدرت بازدارندگى از رشد يرگنه جدايه يرآزارتر بيمـارگر

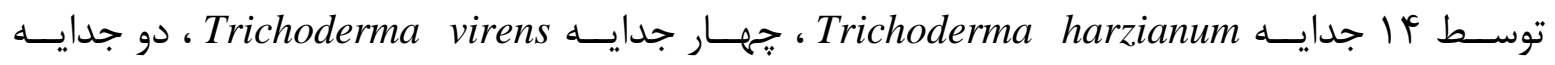
P. florescens CHAO و و و و Pseudomonas florescens و جدايه بـومى در شرايط آزمايشگاهى با توانايى فرا انگلى و توليد مواد يادزيست بررسى شدند. سرانجام تاثير تهار جدايه

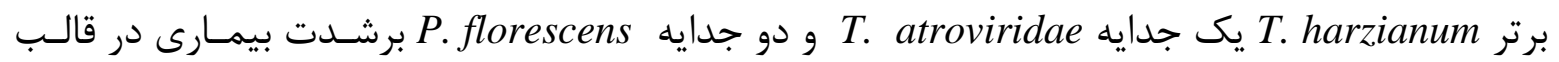

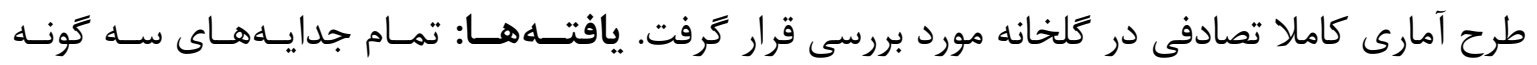
توانايى فرا انگلى و از بين بردن ريسـهـــاى بيمـاركر را داشـتـد. در آزمـايش توليـد مـواد

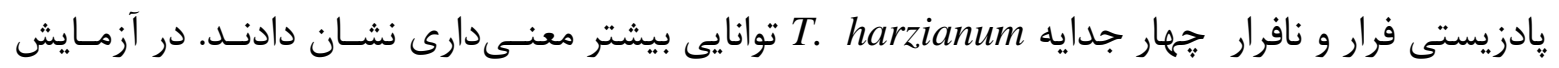

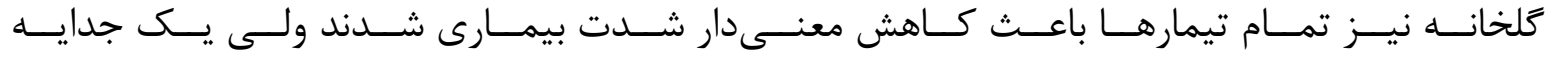
T. Harzianum در جنوبغربى ايران هـم وجـود دارد. جدايـههـاى بـومى T. atroviridae و virens ، T. harzianum توانايى فرا انگلى بيماركر را دارند. اين قارجها و جدايههـاى بـاكترى Pseudomonas florescens توانـايى

\مسئول مكاتبه: msadravi@yu.ac.ir 
مهار زيستى يوسيدگى فوزاريومى ريشه لوبيا با دو كونه Pseudomonas fluorescens و Trichoderma رستمى و همكاران

بازدارندگى از رشد يركنه بيماركر با توليد مواد پادزيستى دارند. جدايههاى Trichoderma harzianum و P. توانايى كاهش شدت بيمارى را در شرايط كلخانه دارند. P. florescens CHAOو T. atroviridae وازَّان كليدى: لوبيا، بيمارى، Fusarium، فرا انخلى، پادزيستى

\section{Introduction}

حبوب پِ از غلات مههترين منبع غذايى بشر و لوبيـا ( Phaseolus vulgaris L. از مهمتـرين آنهـا در جهان محسوب مسىشـود (Parsa and Bagheri 2008). بيمـارى يوسـيدگى فوزاريـومى ريشـه، ناشسى از

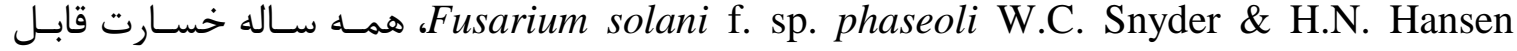
ملاحظهاى را به كشاورزان تحميل مىنمايد، به طورى كه در مناطق كاملا آلوده، تا هم درصد محصـول را از بين مىبرد(Hall 1991). بيماركر به صورت كلاميدوسيور كه داراى ديوارههاى ضخيم مىباشند شـرايط

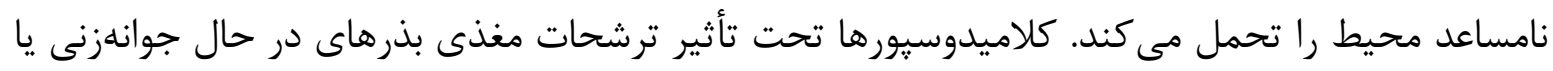
مريستم نوك ريشهها از حالت استراحت خارج شهه و شروع به تندش مى كنند. رخنه مسـتقيم، نفـوذ بـهـ روزنه و زخمها از راههاى ورود بيماركر به درون بافت ريشه لوبيا مىباشند. ريسه بـه راحتـى در فضـاهاى بين سلولى ناحيه يوست ريشه رشد مى كند ولى در مرز سلولهـاى يوست داخلى متوقـف مسىشـود. در

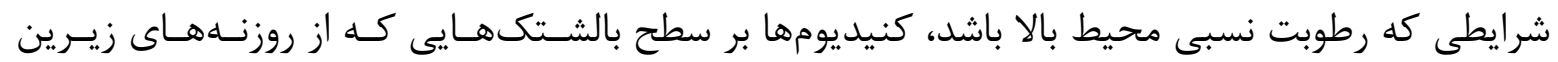
بركَهاى نزديك زمين خارج شدهاند، توليد مى گردنـد. سـرانجام بـا يوسـيدگى كامـل بافـتهـاى آلـوده،

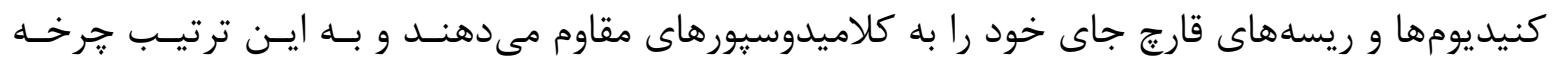
زندگى بيماركر كامل مى گردد(Hall 1991). بيمارى در ايران از اسـتانهـاى خراسـان شـمالى و رضـوى،

مركزى و كهگيلويه و بويراحمد كزارش شده است (Ershad 2009, Gharacheh and Sadravi 2015). روشهاى مبارزه زراعى شامل خاكورزى و زهكشى مناسب خاك، آبيارى و كوددهى بهينه مىتوانند درصد

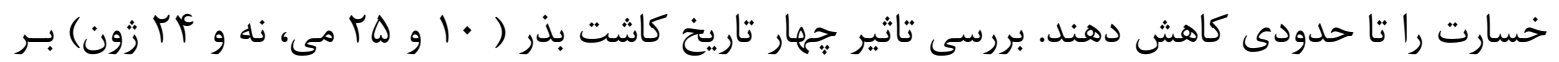

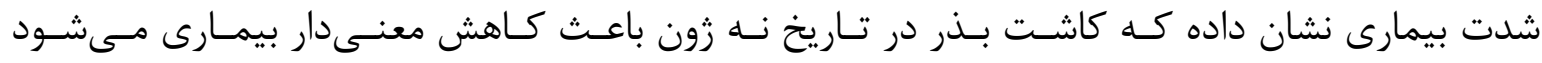
.Lak et al. 2009) مديريت بيمارى به روش شيميايى، با توجه به خاكزاد بودن بيماركر هزينه زيادى به همراه دارد، از سـوى ديكر هم اكثر رقمهاى مقاوم نيز داراى صفتهاى منفى مانند دوره رشد طولانى و دانسهى ريـز مسىباشــند،

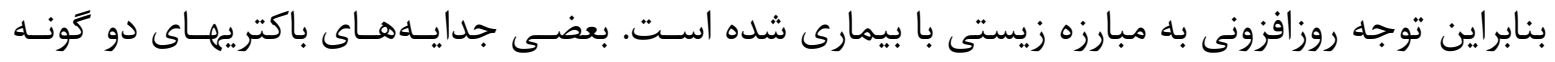
Bacillus 
باعث كاهش معنى دار شـدت بيمـارى شـده اسـت

Rhizobium leguminosarum يـك جدايـه از يـنج جدايـه بـاكترى (MirzaeiGhomi et al. 2010) (Frank 1879) Frank 1889 (Hatamabadi et al. 2010) شدت بيمارى را كاهش داده است جدايه قارج Trichoderma harzianum Rifai نيز شدت بيمـارى را بــه ميـزان معنسى دارى كـاهش داده اسـت

.(Abeysinghe 2007)

نظر به اهميت بيمارى در جهان و كارآيى بهتر مبارزه زيسـتى در مـديريت بيمـارى ايـن يـزوهش بـراى Pseudomonas fluorescens بررسى تـاثير جدايـه هـاى بـومى سـه تونسه Trichoderma و بـاكترى (Flügge 1886) Migula 1895 (بر بيمارگر و شدت بيمارى در شرايط آزمايشگاه و كلخانه انجام شد.

\section{Materials and Methods}

\section{مواد و روشها}

\section{نمونهبردارى، جداسازى، خالصسازى و شناسايى بيماركر}

مزرعههاى لوبياى استان كهزيلويه و بويراحمد بازديد و بوتههاى بيمار بـا نشـانههـاى يوسـيدگى ريشـهـه و طوقه نمونهبردارى شدند و با درج محل نمونهبردارى روى كيسـهـــاى فريـزر بـهـ آزمايشـعاه منتقـل و در يخجال در دماى جهاردرجه سلسيوس نكمهدارى شدند. ريشه و طوقه يوسيده بوتههاى بيمار سه دقيقـه در زير جريان ملايم آب شسته شدند. سيس قطعاتى به طول يك سانتىمتر از قسمت بين بافت بيمار و سالم جدا و به مدت • و ثانيه در هيبو كلريت سديم نيم درصد ضدعفونى شده، سيس با آب مقطر سترون سه بار شسته و يس از خشك كردن با كاغذ صافى روى محيط كشت سـيب زمينسى / دكسـتروز/آكار (PDA) بـهـ

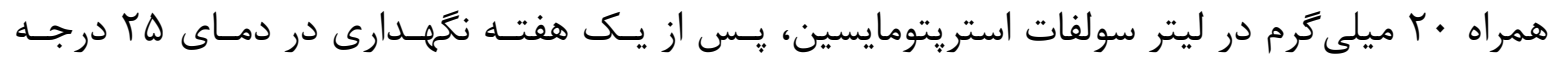

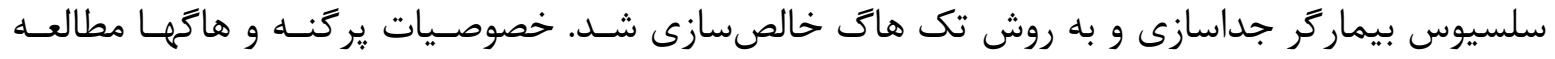

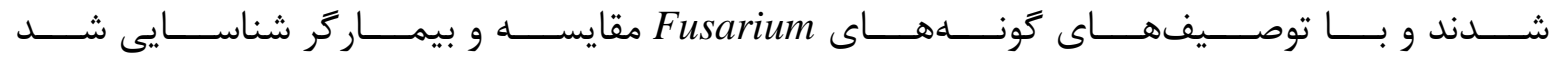

.(Leslie and Summerell 2006)

\section{اثبات بيماريزايى}

زادمايه دو جدايه قارج بيماركر، به دست آمده از مزرعههـاى لوبيـاى ايسن اسـتان، روى دانسهــاى گنــدم سترون تكثير شدند. بذرهاى رقمهاى درخشان (لوبيا قرمز) و ياك (لوبيـا سـفيد) در محلـول هيبوكلريـت سديم نيم درصد به مدت سه دقيقه ضدعفونى شدند و يـس از شستشـو بـا آب مقطـر سـترون در خـاك سترون شده، متشكل از خاك مزرعه و شن، به نسبت 1:ا كاشته شدند. يس از رشد گياهجهها به ازاى هر 
گياهجه، ץ دانه گَندم كلنيزه شده با جدايههاى قارج و در تيمار شاهد كندم سترون شده همراه با محـيط كشت بدون قارج كنار ريشه آنها كذاشته شد. يس از ظهور نشانههاى بيمارى لكـههـاى يوسـيده طوقـه و ريشه با دقت اندازهگيرى شد (Lak et al. 2009). دادههاى حاصل به كمك نرمافزار SPSS20 مورد تجزيه واريانس قرار گرفته و ميانگينهها با آزمايش جند دامنهاى دانكن مقايسه شـدند. از بافتهـاى بيمـار، يـس از ضدعفونى سطحى آنها و كشت روى محيط PDA، قارج جداسازى شـد و خصوصـيات ريخـتشناسـى آن مطالعه و با قارج تلقيح شده مقايسه شد.

آزمايش اثر بازدارندگى جدايههاى ســه كونسه Trichoderma و Psudomonas floresens روى بيمارگر در آزمايشگاه

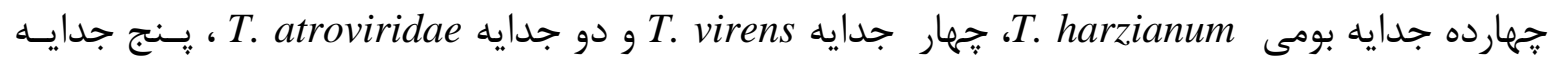
بومى P. florescens و جدايه P. florescens CHAO انتخاب شدند. آزمايش فرا انگلى با قرار دادن قرصى به قطر ه ميليمتر از يركنه جدايه گيرآزارتر بيمارگر در كنار قرصى به

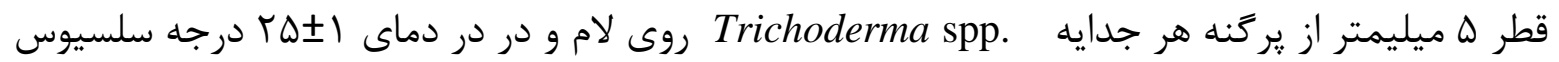
انجام شد (Valed Saravi et al. 2011). بعد از سه روز، جُخونكى تأثير و ارتباط قارجها در روى لامهـا در زير ميكروسكوب بررسى گرديد.

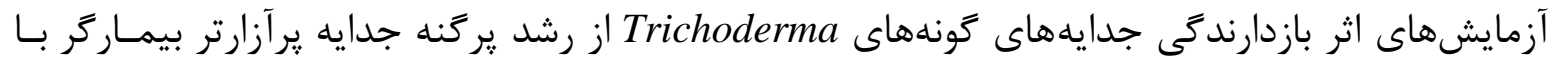
توليد مواد يادزيستى نافرار در كشت متقابل و مواد يادزيستى فـرار بــر اسـاس روش (Desai et al. 2002) در قالب طرح كاملا تصادفى با جهار تكرار براى هر تيمار انجام شدند. آزمايشهاى اثر بازدارندگى جدايههاى P. florescens از رشد يرگنه جدايه برآزارتر بيمارگر بـا توليـد مـواد ֶادزيستى نافرار و فرار به روش (Akbari et al. 2006) در قالب طرح كاملا تصادفى با جهار تكرار براى هر تيمار انجام شدند.

درصد بازدارندگى از رشد يرگنه بيمارگر در آزمايشهاى فوق با استفاده از اين فرمول محاسبه شـد: درصـد

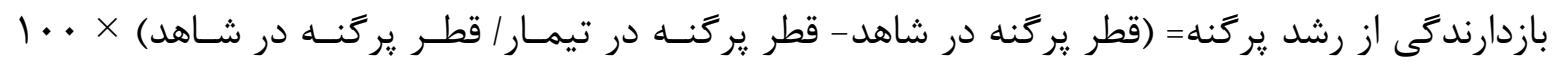
.(Khalili et al. 2012)

اثر جدايههاى برتر تونههاى Prichoderma و P. floresens بر شدت بيمارى در كلخانه جدايههاى برتر گونهاى Trichoderma و كه در آزمايش هاى يادزيستى اثر خوبى بر 
بيماركر داشتند و جدايه يرآزارتر بيماركر براى آزمايش كلخانهاى انتخــاب شــند. بـذرهاى سـترون شـده لوبياى رقم درخشان بهمدت كا سـاعت در آب سـترون خيسـانده شـدند، سـيس در كلـدانهـاى حـاوى

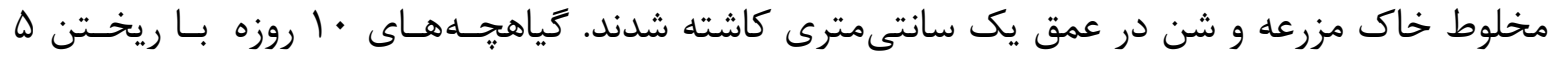

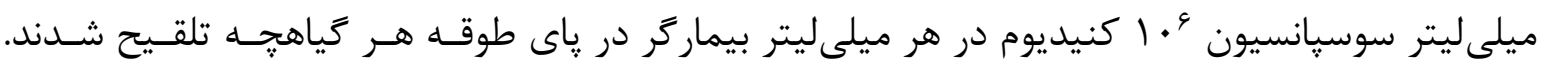
بيست و جهارساعت بعد، له ميلىليتر سوسيانسيونهاى هاگ جدايههاى هر گونه Trichoderma با غلظت

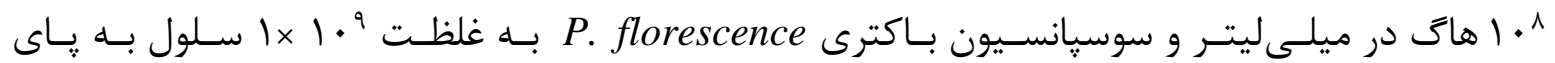
كَياهجهها ريخته شدند( MirzaeiGhomi et al. 2010 ). بسته به نياز آبى كلدانها، هـر روز يـك بـار بـهـ كلدانها آب داده شد. آزمايش در ه تكرار براى هر تيمار و هر تكرار شـامل با كياهجــى لوبيـا، در قالـب طرح كاملا تصادفى اجرا شد. پِ از ظهـور نشـانههـاى بيمـارى و زردى كامـل بوتـهــاى تيمـار شـاهد، لكههاى يوسيده طوقه و ريشه، طول ريشه وساقه و وزنهاى تر و خشك بوتهها اندازهيرى شد. دادهــاى حاصل به كمك نرمافزار SPSS20 مورد تجزيه واريانس قرار كرفته و ميانكَينها با آزمايش خنــد دامنـهاى دانكن مقايسه شدند.

\section{Results}

يافتهها

\section{نشانه هاى بيمارى و ريختشناسى بيماركر}

نشانههاى بيمارى در مزرعههاى لوبياى استان كهخيلويه وبوير احمد به شكل زردى بوتهــا بـا ريشـهـــاى قهوهاى تيره و يوسيده بود (شكل ()). ريختشناسى دو جدايه Fusarium solani f.sp. phaseoli از اين بوتهاى بيمار به اين شرح بود: يركنه سفيد تا كرم رنگ، كنيديومبر روشن، ساده، كاهى اوقات به بلندى طول ماكروكنيديوم بودند. كنيديومها از فياليدها زاده شده بودند، روشن و به دو شكل ديده شدند: ماكروكنيديومها بيضىشكل سه تا ينج سلولى،

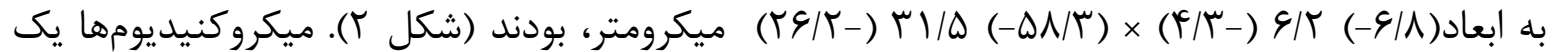

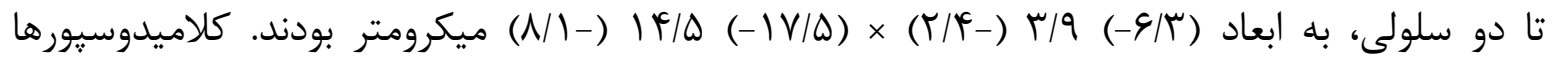
قهوهاى، كروى تا تخممرغى شكل با ديواره صاف و ضخيم، در ريسه به صورت بين سلولى يا انتهايى،

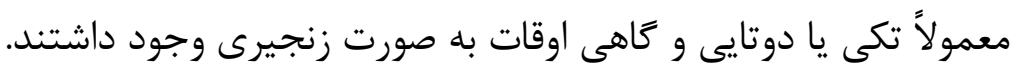



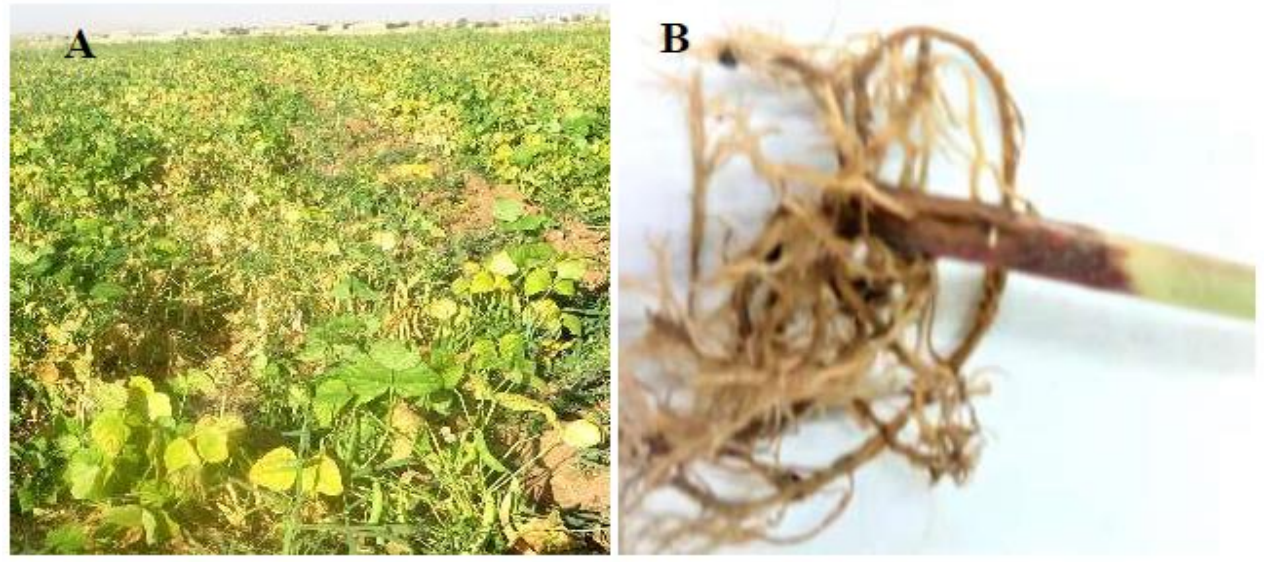

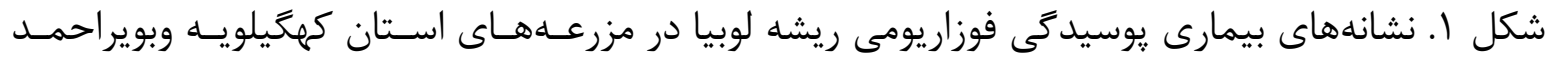

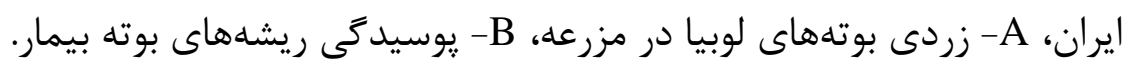
Figure 1. Symptoms of Fusarium root rot of bean in fields in Kohgiluyeh and BoyerAhmad Province of Iran, A- Yellowing of bean plants in the field, B- Root rot of diseased plant.
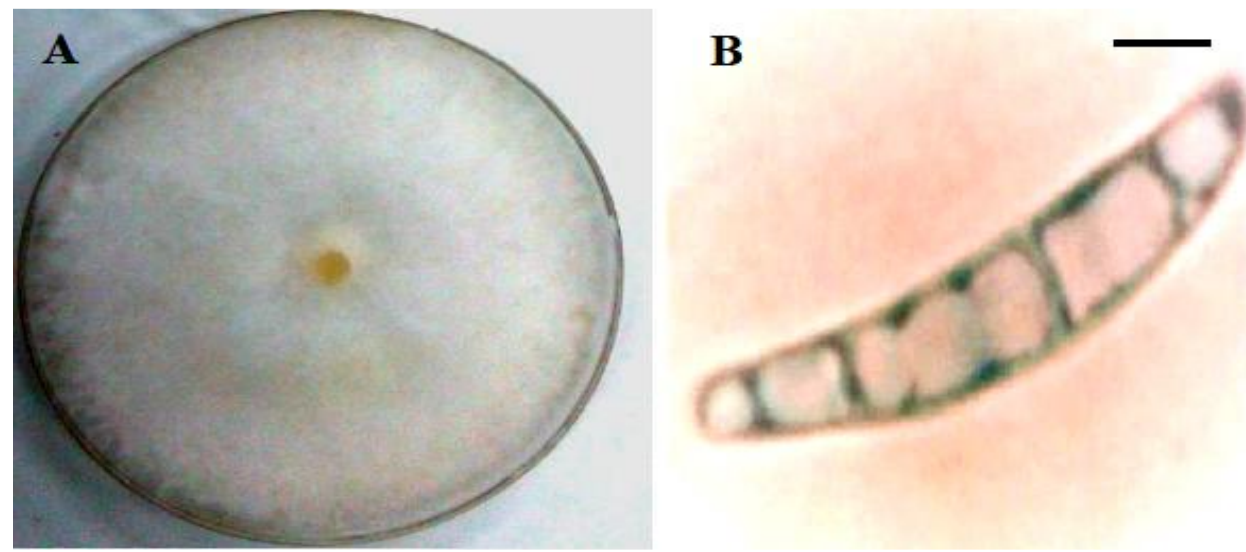

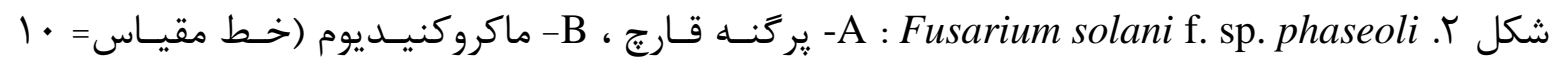
ميكرومتر).

Figure 2. Fusarium solani f. sp. phaseoli: A- Colony, B-Macrocondium (Bar=10um).

\section{بيمارىزايـى جدايههاى بيماركر و واكنش رقمهاى لوبيا به آنها}

تجزيه واريانس دادههاى اين آزمايش نشان داد كه قدرت بيماريزايى جدايههاى بيمـاركر در سـطح يـى درصد داراى اختلاف معنى دارى با يكديكر هستند و جدايه يـك از منطقـه تـلـسـرو قـدرت بيمـاريزايى بيشترى نسبت به جدايه تنگ مهريان دارد، ولى واكنش رقمهاى ياك و درخشان نسبت بـهـ آنهـا اخــلاف 
جدول ا. بيماريزايى دو جدايه Fusarium solani f. sp. phaseoli از استان كهگيلويه وبويراحمد ايران بر دو رقم لوبيا.

Table 1. Pathogenicity of two isolates Fusarium solani f. sp. phaseoli from Kohgiluyeh and Boyer Ahmad Province of Iran on two bean cultivars*.

\begin{tabular}{lc}
\hline Treatment & $\begin{array}{c}\text { Root rot lesion } \\
\text { length } \\
(\mathrm{mm})\end{array}$ \\
\hline Fusarium solani f. sp.phaseoli $1 \times$ Pak cultivar & $40.05 \mathrm{a}$ \\
Fusarium solani $\mathrm{f}$. sp.phaseoli $1 \times$ Derakhshan cultivar & $38 \mathrm{a}$ \\
Fusarium solani $\mathrm{f}$. sp.phaseoli $2 \times$ Derakhshan cultivar & $28.70 \mathrm{~b}$ \\
Fusarium solani f. sp.phaseoli $2 \times$ Pak cultivar & $27.75 \mathrm{~b}$
\end{tabular}

*Numbers with similar letters do not differ significantly at the $1 \%$ level (DMRT).

معنى دارى نداشته و هر دو حساس هستند. نتيجه مقايسه ميانكين دادههاى اين آزمايش در جـدول يـى نشان داده شده است. مطالعه خصوصيات ريختشناسى قارج جداسازى شــهـ نشـان داد كــه همـان قـارتج تلقيح شده است.

اثر جدايه هاى گونـههــاى Pseudomonas floresence و Trichoderma بـر بيمــاركر در شــرايط آزمايشگاه

بررسى اسلايدهاى ميكروسكيى تهيه شده از آزمايش فرا انگلىى، با يك ميكروسكٍ كاليبره شـده و متصـل به رايانه جهت عكسبردارى، اين نتيجه حاصل شد كه هر سه گونه Trichoderma داراى توانايى فرا انگلى با پيجشش به دور ريسه Fusarium solani f.sp. phaseoli هستند (شكل r)

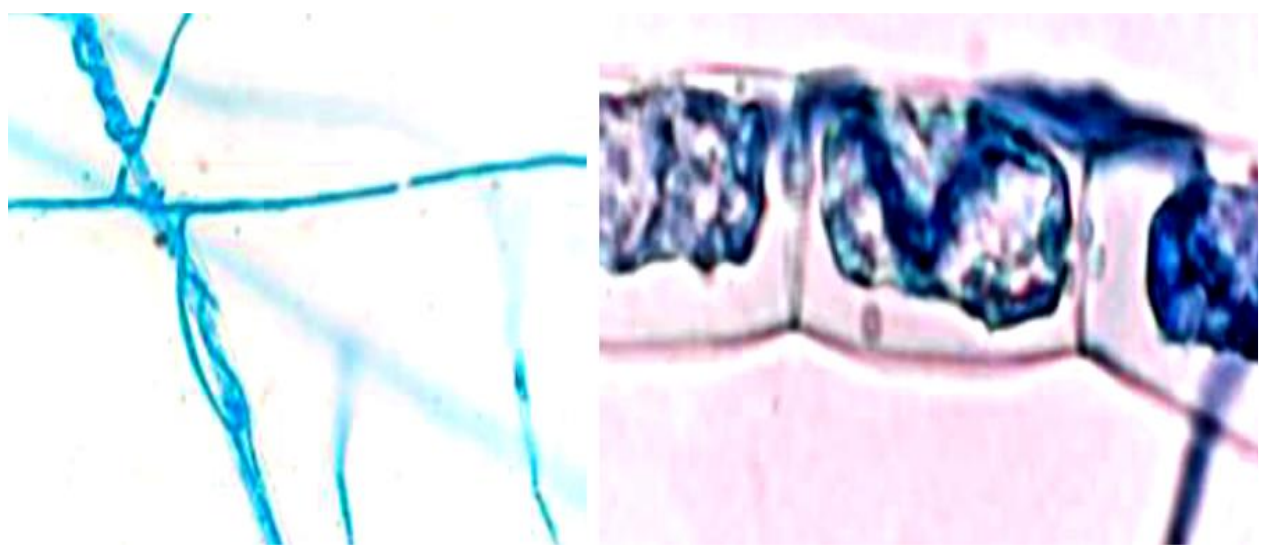

شكل س. ييجيدن ريسه Trichoderma harzianum به دور ريسه Fusarium solani f. sp. phaseoli. Figure 3. Twisting of Trichoderma harzianum hyphae around Fusarium solani f. sp. phaseoli hyphae. 
مهار زيستى يوسيدگى فوزاريومى ريشه لوبيا با دو كونه Pseudomonas fluorescens و Trichoderma رستمى و همكاران

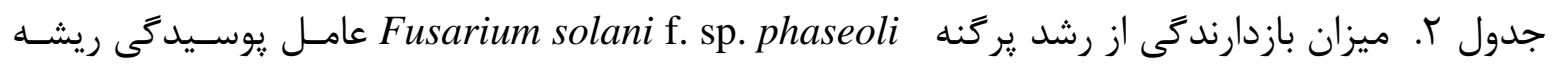

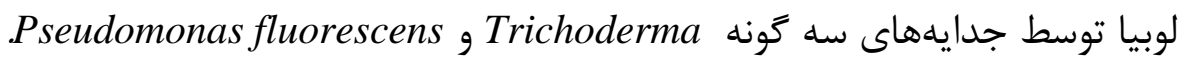

Table 2. Colony growth inhibition of Fusarium solani f. sp. phaseoli the causal of root rot of bean by isolates of three Trichoderma species and Pseudomonas fluorescens*.

\begin{tabular}{|c|c|c|}
\hline \multirow[b]{2}{*}{ Treatment } & \multicolumn{2}{|c|}{ Colony growth Inhibition (\%) } \\
\hline & $\begin{array}{l}\text { Dual culture } \\
\text { test }\end{array}$ & $\begin{array}{c}\text { Volatiles } \\
\text { antibiotics } \\
\text { production test }\end{array}$ \\
\hline T. harzianum 42 & $65.35 \mathrm{a}$ & $64.35 \mathrm{hi}$ \\
\hline T. harzianum 38 & $64.56 \mathrm{a}$ & $20.08 \mathrm{jk}$ \\
\hline T. harzianum 14 & $63.77 \mathrm{a}$ & $51.41 \mathrm{bc}$ \\
\hline T. harzianum 39 & $62.20 \mathrm{ab}$ & 47.63 c-e \\
\hline T. harzianum 40 & $62.20 \mathrm{ab}$ & $44.47 \mathrm{~d}-\mathrm{f}$ \\
\hline T. harzianum 17 & $50.90 \mathrm{bc}$ & $33.75 \mathrm{i}$ \\
\hline T. harzianum 36 & $45.33 \mathrm{~cd}$ & $54.88 \mathrm{ab}$ \\
\hline T. harzianum 10 & $54.33 \mathrm{~cd}$ & $44.79 \mathrm{~d}-\mathrm{f}$ \\
\hline T. harzianum 43 & $51.96 \mathrm{c}-\mathrm{e}$ & $44.16 \mathrm{~d}-\mathrm{f}$ \\
\hline T. harzianum 45 & $50.39 \mathrm{c}-\mathrm{f}$ & $58.35 \mathrm{a}$ \\
\hline T. atroviridae 23 & $48.81 \mathrm{c}-\mathrm{g}$ & $47.91 \mathrm{~cd}$ \\
\hline T. virense 4 & $47.24 \mathrm{~d}-\mathrm{h}$ & $21.76 \mathrm{jk}$ \\
\hline T. virense 18 & 46.45 e-h & $42.58 \mathrm{~d}-\mathrm{g}$ \\
\hline T. harzianum 9 & $45.66 \mathrm{e}-\mathrm{h}$ & $24.19 \mathrm{kl}$ \\
\hline T. harzianum 25 & $44.09 \mathrm{f}-\mathrm{h}$ & $40.06 \mathrm{f}-\mathrm{h}$ \\
\hline T. harzianum 27 & $44.09 \mathrm{f}-\mathrm{h}$ & $19.31 \mathrm{~d}-\mathrm{f}$ \\
\hline T. harzianum 33 & $43.30 \mathrm{f}-\mathrm{h}$ & $54.57 \mathrm{ab}$ \\
\hline T. harzianum 12 & 41.73 ghi & $32.17 \mathrm{i}$ \\
\hline Pseudomonas & & \\
\hline $\begin{array}{l}\text { florescence } \\
\text { (CHAO) }\end{array}$ & $40.88 \mathrm{hi}$ & $30.34 \mathrm{~d}-\mathrm{f}$ \\
\hline$P$. florescence 16 & $35.22 \mathrm{i}$ & 16.451 \\
\hline T. harzianum 3 & $21.77 \mathrm{j}$ & 47.00 c-e \\
\hline P. florescence 2 & $21.06 \mathrm{j}$ & $37.34 \mathrm{~g}-\mathrm{i}$ \\
\hline P. florescence (PF1) & $20.75 \mathrm{j}$ & 14.241 \\
\hline T. atroviridae 5 & $21.25 \mathrm{jk}$ & $26.81 \mathrm{j}$ \\
\hline P. florescence 57 & $16.66 \mathrm{kl}$ & $42.08 \mathrm{~d}-\mathrm{f}$ \\
\hline P. florescence (PF2) & 11.941 & $22.40 \mathrm{jk}$ \\
\hline
\end{tabular}

*Numbers with similar letters do not differ significantly at the $1 \%$ level (DMRT).

تجزيه واريانس دادهاى آزمايشهاى اثر يادزيستى جدايههاى سه گونه Trichoderma و باكترى روى بيمارَّر در آزمايشًاه نشان داد كه همهى جدايههاى سه كَونه 
Trichoderma و جدايههاى باكترى Pseudomonas florescence در كشت متقابل و توليد مـواد نـافرار يادزيستى توانايى بازدارندكى از رشد يركنه قارج بيماركر را داشته و در سطح يك درصد با يكديكر تفـاوت

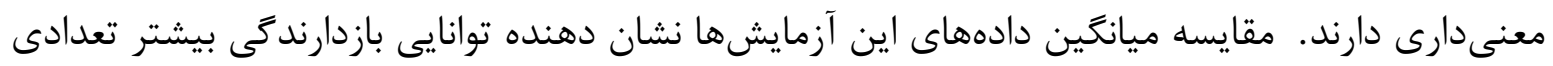
از جدايههاى Tarzianum . hاشت (جدول ؟ ).

تاثير جدايههاى برتر دو تونه Pseudomonas florecens و Trichoderma شــــ بيمـارى در كلخانه

تجزيه واريانس دادهاى اين آزمايش كه با جهارجدايهى برتر 42,45,38,14 harzianum .T. يك جدايهى P. florescence CHAO، T. atroviridae 23 بين تيمارها اختلاف معنى دارى در سطح يك درصد وجود دارد. مقايسه ميانگينهـا نشـان داد كـه تمـام تيمارهاى جدايههاى كونههاى Prichoderma و اعث كاهش معنى دار شدت بيمارى و و

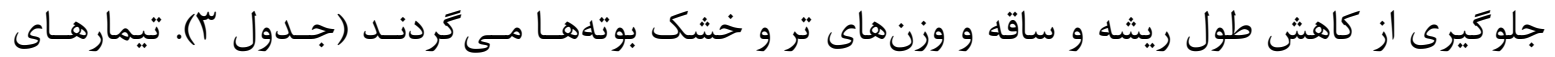
T. harzianum 38,42 نه تنها شدت بيمارى را به طور معنى دارى كاهش دادند، بلكه طول ريشـه و سـاقه بوتهاى اين تيمارها با بوتهاى شاهد سالم اختلاف معنى دارى نداشت.

\section{Discussion}

توانايى فرا انغلى كونههاى Trichoderma ، مخصوصا Tarzianum بر ساير قارجها مانند Rhizoctonia عolani Kohn

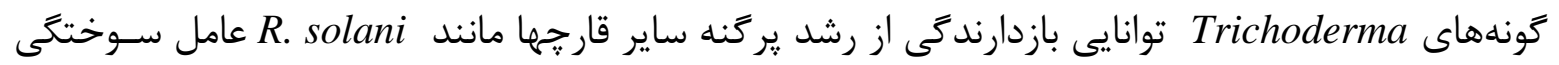
غلاف بركَ برنج و .Bipolaris oryzae Breda de Hann عامل بيمارى لكه قهوه اي برنج، بـا توليـد مـواد

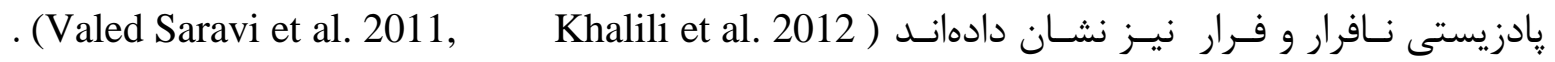
متابوليتهاى پادزيستى كونهاى Trichoderma شامل آنزيمهاى كيتيناز، لاميناريناز، بتا اوس گلوكوناز و

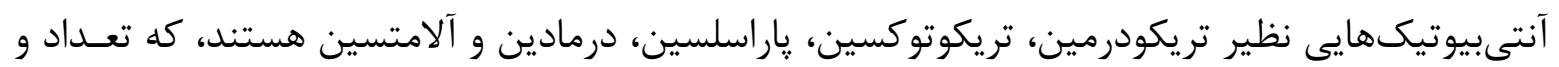

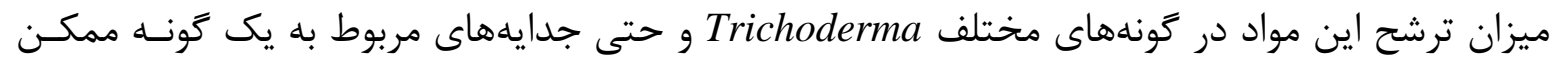
است متفاوت باشد. همجنين استالدئيد به عنوان مهمترين متابوليت فرار بعضى گونههاى Trichoderma 
مهار زيستى يوسيدگى فوزاريومى ريشه لوبيا با دو كونه Pseudomonas fluorescens و Trichoderma رستمى و همكاران

جدول س. اثر جدايههاى دو گونه Pseudomonas fluorescens و Trichoderma بر بيمارى يوسـيدگى فوزاريومى ريشه لوبيا ناشى از Fusarium solani f. sp. phaseoli در كلخانه.

Table 3. The effect of isolates of two Trichoderma species and Pseudomonas fluorescens on Fusarium root rot disease of bean caused by Fusarium solani f. sp. phaseoli in vivo*.

\begin{tabular}{|c|c|c|c|c|c|}
\hline Treatment & $\begin{array}{c}\text { Root rot } \\
\text { lesion } \\
\text { length } \\
(\mathrm{mm})\end{array}$ & $\begin{array}{l}\text { Root } \\
\text { length } \\
(\mathrm{cm})\end{array}$ & $\begin{array}{l}\text { Stem } \\
\text { length } \\
(\mathrm{cm})\end{array}$ & $\begin{array}{c}\text { Wet } \\
\text { weight } \\
(\mathrm{gr})\end{array}$ & $\begin{array}{c}\text { Dry } \\
\text { weight } \\
\text { (gr) }\end{array}$ \\
\hline Check (Diseased) & $30.95 \mathrm{a}$ & $13.49 \mathrm{~d}$ & $40.55 \mathrm{c}$ & $13.16 \mathrm{f}$ & $1.97 \mathrm{~d}$ \\
\hline T. harzianum 38 & $25.45 \mathrm{~b}$ & $20.93 \mathrm{ab}$ & $58 \mathrm{a}$ & $19.58 \mathrm{bc}$ & $2.77 \mathrm{ab}$ \\
\hline T. harzianum 14 & $20.25 \mathrm{c}$ & $17.66 \mathrm{c}$ & $50.15 \mathrm{~b}$ & $16.94 \mathrm{de}$ & $2.79 \mathrm{ab}$ \\
\hline T. harzianum 45 & $24.50 \mathrm{~b}$ & $17.42 \mathrm{c}$ & $49.40 \mathrm{~b}$ & $16.76 \mathrm{e}$ & $2.57 \mathrm{bc}$ \\
\hline T. harzianum 42 & $24.70 \mathrm{~b}$ & $21.89 \mathrm{a}$ & $59.70 \mathrm{a}$ & $20.07 \mathrm{~b}$ & $2.64 \mathrm{bc}$ \\
\hline P. florecsens $\mathrm{CHAO}$ & $24.70 \mathrm{~b}$ & $19.76 \mathrm{~b}$ & $51.20 \mathrm{~b}$ & $18.36 \mathrm{~cd}$ & $2.58 \mathrm{bc}$ \\
\hline T. atroviridae 23 & $24.70 \mathrm{~b}$ & $17.34 \mathrm{c}$ & $49.75 \mathrm{~b}$ & $16.57 \mathrm{e}$ & $2.60 \mathrm{bc}$ \\
\hline P. florecsens 57 & $25.95 \mathrm{~b}$ & $16.91 \mathrm{c}$ & $49.55 \mathrm{~b}$ & $16.04 \mathrm{e}$ & $2.36 \mathrm{c}$ \\
\hline Check (Healthy) & $0 \mathrm{~d}$ & $20.20 \mathrm{a}$ & $59.70 \mathrm{a}$ & $22.61 \mathrm{a}$ & $3.02 \mathrm{a}$ \\
\hline
\end{tabular}

*Numbers with similar letters do not differ significantly at the $1 \%$ level (DMRT).

تشـخيص داده شـده است (Harson et al. 1996, Howell 2003). بعضى گونسههـاى Trichoderma) ميتوانند باعث افزايش توليد هورمونهاى گياهى شامل اكسينها، سيتوكنينها و اتيلن شوند، كه موجـب افزايش رشد و ترميه بافتهاى آسيبديده گياهان و كاهش شدت بيماريها ميكردند. آنها همجنين محيط اطراف خود را با ترشح اسيدهاى آلى همجون اسيد گلوكونيك، اسيد سيتريك و اسيد فوماريـك، اسـيدى مى كنند و شرايط را براى قابل جذب شدن فسفر، آهن، منكَنز و منيزيوم فراهم مى كنند كه خود منجر به رشد بيشتر و سريعتر زياهان مىشوند (Harmen et al. 2004). جدايههاى باكترى P. fluorescens به طور مـوثرى توانسـتند از رشــد بيمـارگر در شـرايط آزمايشـعاهى جلو كيرى كنند و از شدت بيمارى در شرايط كلخانه بكاهند. يـك جدايـه ايـن بـاكترى شـدت ثرمردكىى

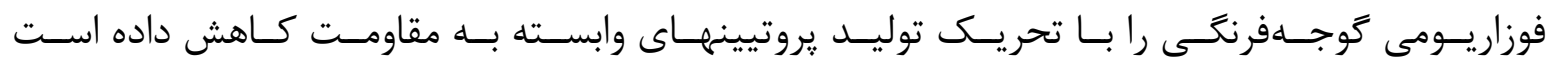




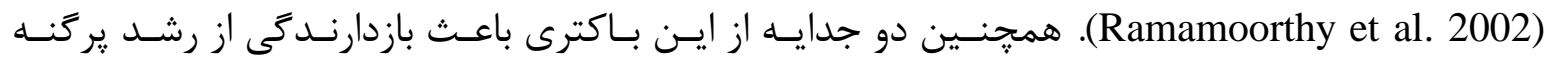
R. solani

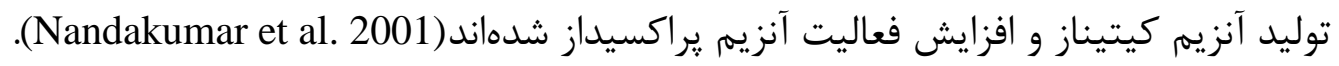
P. fluorescens CHAO Thielaviopsis basicola (Berk \& Broome) Ferraris سيدروفور و اسيد سيانيك جلوكيرى كرده است (Ahl et al. 1986).

\section{Conclusion}

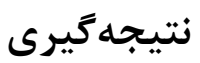

Fusarium solani f. sp. phaseoli اسـت. جدايـههـاى بـومى T. atroviridae ، T. virens ، Trichoderma harzianum و جدايسهـــاى با توانايى فرا انگلى و توليد مواد پادزيستى نافرار و فرار قادر به بازدارندگى از Pseudomonas florescens

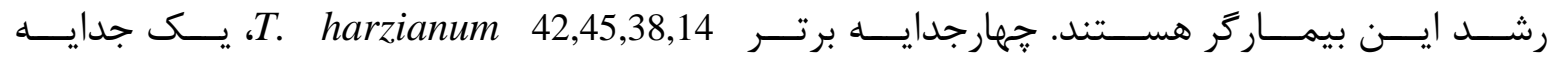
P. florescence CHAO ، T. atroviridae 23 شدت بيمارى در كلخانه شدند، بنابراين از آنها مىتوان براى مهارزيسـتى بيمـارى يوسـيدگى فوزاريـومى ريشه لوبيا استفاده كرد.

\section{References}

1. Abeysinghe S (2007) Biological control of Fusarium solani f. sp. phaseoli the causal agent of root rot of bean using Bacillus subtilis CA32 and Tichoderma harzianum RU01. Ruhuna Journal of Science 2:82-88.

2. Ahl P, Voisard C, Défago G (1986) Iron bound- siderophores, cyanic acid, and antibiotics involved in suppression of Thielaviopsis basicola by a Pseudomonas fluorescens strain. Journal of Phytopathology https://doi.org/10.1111/j.14390434.1986.tb00903.x

3. Akbari A, Zafari DM, Rouhani H, Khodakaramian G (2006) Study of antagonistic activity of Bacillus species from bean rhizosphere against root rot caused by Fusarium solani f. sp. phaseoli. Agricultural Research 5(3):54-70.

4. Desai S, Reddy M S, Kloepper M S(2002). Comprehensive testing of biological agents. Pp: 387-420, In: S. S. Gnanamanickam (Ed.). Biological Control of Crop Diseases. Marcel Dekker Inc., New York, USA. 
مهار زيستى يوسيدگى فوزاريومى ريشه لوبيا با دو گونه Pseudomonas fluorescens و Trichoderma رستمى و همكاران

5. Ershad D (2009) Fungi of Iran. Iranian Research Institute of Plant Protection. Tehran, Iran, 558p.

6. Gharacheh N, Sadravi M (2015) Five important fungal diseases of pulse crops in Iran. Plant Pathology Science 4(2):17-25.

7. Hall R (1991) Compendium of Bean Disease. APS Press, USA.

8. Harman, G. E., Howell, C. R., Viterbo, A., Chet, I. and Lorito, M. 2004. Trichoderma species opportunistic, avirulent plant symbionts. Nat Rev Micro. 2: 43-56.

9. Harson, S., Schichler, H., Oppenhim, A., and Chet, I. (1996). Defferential expression of Trichoderma harzianum chitinases during mycoparasitism. Phytopathology. 86: 980985.

10. Hatamabadi Farahani M, Rezaei S, Lak MR (2010) The effect of Rhizobium leguminosarum strains on Fusarium root rot disease of bean. Agroecology Journal 5:1-8 (In Persian with English abstract).

11. Howell, C.R. (2003). Mechanism employed by Trichoderma species in biological control of plant diseases: The history and evolution of current concepts. Plant Disease: 87: 4-10.

12. Khalili E, Sadravi M, Naeimi S , Khosravi V (2012) Biological control of rice brown spot with native isolates of three Trichoderma species. Brazilian Journal of Microbiology 43(1):297-305.

13. Lak MR, Ghanbari A A, Dori HR, Ghadiri A (2009) Effect of planting date on seed yield and Fusarium root rot disease severity in chitti bean in Khomein. Seed and Plant Production Journal 25(3):271-282.

14. Leslie, J. F. and B. A. Summerell. (2006). The Fusarium Laboratory Manul. Blackwell Publishing. 387 pp

15. MirzaeiGhomi P, Zamanizadeh HR, SaberiRiseh RA, Lak MR (2010) Powder formulation survey of strain Bacillus subtilis M36 for control of bean root rot, caused by Fusarium solani f.sp. phaseoli. Iranian Journal of Plant Protection Science 41(1):151163.

16. Parsa M, Bagheri A (2008) Legumes. JDM Press, Mashhad, Iran. (In Persian)

17. Ramamoorthy V, Raguchander T, Samiyappan R (2002) Induction of defenserelated proteins in tomato roots treated with Pseudomonas fluorescens Pf1 and Fusarium oxysporum f. sp. lycopersici. Plant and Soil 239:55-68. 


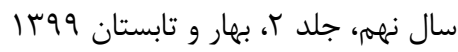

دانش بيمارىشناسى كياهى

Plant Pathology Science

18. Valed Saravi Z, Sadravi M, Bahrami M (2011) Efect of three biological products on rice sheath blight disease in the field. Journal of Plant Protection 25(1):44-49 (In Persian with English abstract). 